\section{Alterations in Leaf Morphology of Two Landscape Shrubs in Response to Disparate Climate and Paclobutrazol}

\author{
Chris A. Martin and William P. Sharp \\ Department of Botany, Arizona State University, Tempe, AZ 85287
}

\author{
John M. Ruter \\ Department of Horticulture, University of Georgia, Coastal Plain Experiment \\ Station, Tifton, GA 31793 \\ Richard L. Garcia \\ United States Water Conservation Laboratory, 4331 East Broadway, Phoenix, \\ AZ 85040
}

Additional index words. growth regulator, landscape horticulture, Feijoa sellowiana, Ligustrum japonicum

\begin{abstract}
Paclobutrazol at 0 and $750 \mu l \cdot{ }^{-1 i t e r}{ }^{-1}$ was sprayed on shoots of Feijoa sellowiana O. Berg. and Ligustrum japonicum Thunb. grown under similar production regimes in central Arizona (subtropical desert) and southern Georgia (humid temperate). Five months after application, Feijoa and Ligustrum leaves were generally smaller and thicker in Arizona than in Georgia. Arizona leaves were thicker than those in Georgia because of more layers of palisade and spongy mesophyll cells. Compared with leaves from control plants, paclobutrazol 1) increased Feijoa leaf area in Georgia, 2) decreased Ligustrum leaf area at both locations by $\approx 50 \%$, and 3 ) decreased leaf thickness of both species in Arizona. Arizona Feijoa leaves had trichomes on adaxial and abaxial surfaces, whereas Georgia Feijoa leaves had trichomes on abaxial surfaces only. Paclobutrazol increased trichome frequency on adaxial surfaces of Arizona Feijoa leaves. Stomatal frequency of Georgia Feijoa leaves was about doubled by paclobutrazol. Reflectance of near-infrared radiation by paclobutrazol-treated Feijoa leaves was 1.4 times higher than that of nontreated leaves in Georgia and 1.9 times in Arizona. Near-infrared reflectance by Georgia Ligustrum leaves was 1.3 times higher than by Arizona Ligustrum leaves and was not affected by paclobutrazol. Leaf reflectance of photosynthetically active radiation (PAR) by Arizona Feijoa was higher than by Georgia Feijoa. Paclobutrazol increased PAR reflectance by Arizona Feijoa leaves. In contrast, Georgia Feijoa PAR reflectance was decreased by paclobutrazol. Paclobutrazol or location did not affect Ligustrum PAR reflectance.

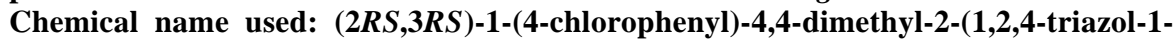
yl)pentan-3-ol (paclobutrazol).
\end{abstract}

Chemical regulators are commonly used to retard growth of potted flowering plants, bedding plants, and some fruit crops. Paclobutrazol is a chemical growth retardant that decreases shoot extension and internode length by inhibiting gibberellin biosynthesis (Barrett and Bartuska, 1982; Barrett and Nell, 1983; Marquard, 1985). Paclobutrazol also appears to buffer plant response to environmental stress. Earlier, paclobutrazol was shown to affect root conductivity and water usage of apple (Malus domestica Borkh.) (Swietlik and Miller, 1983; Wieland and Wample, 1985). Ruter and Martin (1994) found that paclobutrazol lowered whole-plant transpiration of two landscape plants, and that this reduction in transpi-

Received for publication 22 Mar. 1994. Accepted for publication 20 June 1994. This research is supported in part by the nursery industry through contributions to the Horticultural Research Institutenonprofit organization devoted to nursery industry progress through research. The cost of publishing this paper was defrayed in part by the payment of page charges. Under postal regulations, this paper therefore must be hereby marked advertisement solely to indicate this fact. nontreated leaves. Conversely, Martin and Ingram (1988) noted paclobutrazol did not affect leaf area or thickness of southern magnolia (Magnolia grandiflora Hort. 'Glen St. Mary'). Although recent research has evaluated the growth effects of paclobutrazol on ornamental landscape trees and shrubs (Keever et al., 1990; Martin and Ingram, 1988; Owings and Newman, 1993; Ruter, 1992; Ruter and Martin, 1994; Wheeler, 1987), to our knowledge, no studies have been conducted to explore the interaction of environmental factors and paclobutrazol on leaf morphology of woody ornamental landscape plants. For ornamental plants, our understanding of the interactive effects of paclobutrazol and climate on leaf morphology is critical because of possible affects on plant aesthetics and subsequent market value. Thus, the objective of this research was to investigate the effects of disparate climate and paclobutrazol on leaf morphology of two landscape shrubs.

\section{Materials and Methods}

Growth conditions. Research was replicated using similar experimental protocol at the Arizona State Univ. Horticultural Resource Center in Tempe $\left(33.5^{\circ} \mathrm{N} 112^{\circ} \mathrm{W}\right)$ and the Univ. of Georgia Coastal Plain Experiment Station in Tifton $\left(32^{\circ} \mathrm{N} 83^{\circ} \mathrm{W}\right)$. Same-source, uniform-rooted liners of Feijoa sellowiana and Ligustrum japonicum were transplanted into 2.2-liter $(15-\mathrm{cm}$ top diameter $\times 12-\mathrm{cm}$ bottom diameter $\times 15.5$-cm height) black polyethylene containers on 2 Mar. 1992. The rooting medium consisted of 3 milled pine bark : 1 peatmoss : 1 sand (by volume) amended with micronutrients (Micromax; Grace-Sierra Horticultural Products Co., Milpitas, Calif.) at 0.9 $\mathrm{kg} \cdot \mathrm{m}^{-3}$. Individual containers were topdressed with $18 \mathrm{~N}-2.6 \mathrm{P}-9.9 \mathrm{~K}$ controlled-release fertilizer(Osmocote 18N-6P-12K; Grace-Sierra) in Mar. and Aug. 1992, at the rate of $1.2 \mathrm{~kg} \mathrm{~N} /$ $\mathrm{m}^{3}$ rooting medium. At both locations, plants were watered daily to container capacity at the rate of $15 \mathrm{~mm} \mathrm{H}_{2} \mathrm{O}$ per watering by overhead irrigation so as not to allow development of plant water stress. Paclobutrazol sprays of 0 (deionized water control) and $750 \mu l \cdot$ liter $^{-1}$ in a volume of $4 \mathrm{ml} /$ pot were applied uniformly

Table 1. Effect of location and paclobutrazol (PBZ) on leaf area, specific leaf dry weight (SLW), and stomatal frequency of Feijoa sellowiana and Ligustrum japonicum.

\begin{tabular}{|c|c|c|c|c|}
\hline $\begin{array}{l}\text { Species and } \\
\text { location }\end{array}$ & $\begin{array}{c}\text { PBZ } \\
\text { concn } \\
\left(\mu \mathrm{l} \cdot \text { liter }^{-1}\right)\end{array}$ & $\begin{array}{l}\text { Leaf } \\
\text { area } \\
\left(\mathrm{cm}^{2}\right)\end{array}$ & $\begin{array}{c}\mathrm{SLW} \\
\left(\mathrm{mg} \cdot \mathrm{cm}^{-2}\right)\end{array}$ & $\begin{array}{l}\text { Stomatal } \\
\text { frequency } \\
\left(\text { no. } / \mathrm{mm}^{2}\right)\end{array}$ \\
\hline \multicolumn{5}{|l|}{$\overline{\text { Feijoa }}$} \\
\hline \multirow[t]{2}{*}{ Arizona } & 0 & $9.4 b c^{2}$ & $19.6 \mathrm{a}$ & $1101 \mathrm{a}$ \\
\hline & 750 & $7.6 \mathrm{c}$ & $14.7 \mathrm{~b}$ & $1286 \mathrm{a}$ \\
\hline \multirow{2}{*}{ Georgia } & 0 & $13.5 \mathrm{~b}$ & $13.0 \mathrm{bc}$ & $525 \mathrm{~b}$ \\
\hline & 750 & $19.7 \mathrm{a}$ & $11.7 \mathrm{c}$ & $1100 \mathrm{a}$ \\
\hline$P>\mathrm{F}^{\mathrm{y}}$ (location $\left.\times \mathrm{PBZ}\right)$ & & 0.009 & 0.040 & 0.007 \\
\hline \multicolumn{5}{|l|}{ Ligustrum } \\
\hline \multirow[t]{2}{*}{ Arizona } & 0 & $12.5 \mathrm{~b}$ & $19.3 \mathrm{a}$ & $242 \mathrm{a}$ \\
\hline & 50 & $6.6 \mathrm{~d}$ & $15.7 \mathrm{~b}$ & $263 \mathrm{a}$ \\
\hline \multirow[t]{2}{*}{ Georgia } & 0 & $18.7 \mathrm{a}$ & $15.3 \mathrm{~b}$ & $209 \mathrm{a}$ \\
\hline & 750 & $9.5 \mathrm{c}$ & $15.1 \mathrm{~b}$ & $236 a$ \\
\hline$P>\mathrm{F}$ (location $\times \mathrm{PBZ})$ & & 0.045 & 0.066 & 0.875 \\
\hline
\end{tabular}

${ }^{\mathrm{z}}$ Values are treatment means; $\mathrm{n}=15$ for leaf area and SLW and $\mathrm{n}=10$ for stomatal frequency. Mean separation within a column by species by Tukey's HSD, $\alpha=0.05$.

${ }^{\mathrm{y}}$ Statistical probabilities $(P>\mathrm{F})$ are given by species for the interaction of location $\times \mathrm{PBZ}$. 
to the shoots of both species at both locations on 25 Mar. 1992. Meteorological variables of air and dew point temperature, integrated daily radiation, and rainfall were collected at each location. Mean daily maxima and minima at the Arizona location were 7.2 to $8.3 \mathrm{C}$ and 1.5 to $5.5 \mathrm{C}$ higher than at the Georgia location. Mean daily dew point temperatures at the Georgia location were 4.9 to $13.3 \mathrm{C}$ higher than at the Arizona location. Daily total insolation in Arizona averaged 4.2 to $8.4 \mathrm{MJ} \cdot \mathrm{m}^{-}$ ${ }^{2} \cdot$ day $^{-1}$ higher than in Georgia. Total rainfall during the study period was $187 \mathrm{~mm}$ in Arizona and $423 \mathrm{~mm}$ in Georgia.

Measurements. Five months after application, four replications per treatment combination of Georgia plants were transported to Arizona overnight for analyses of leaf spectral reflectance under the same natural irradiance source and leaf morphology, using scanning electron microscopy (SEM). Before reflectance measurements, all Georgia plants were acclimated to Arizona conditions by placing them under a $30 \%$ light exclusion shade structure for 3 days after which they were moved into full sun for 3 days. Leaf spectral reflectance of all plants was measured under a clear sky on 14 Sept. 1992 at about solar noon (1300 HR). Plants were positioned against a black background, and 10 reflectance measurements per leaf on four leaves per plant were recorded with a PSII spectrometer (Analytical Spectral Devices, Boulder, Colo.). All measurements were made on only the most recently fully expanded leaves that had developed fully under their respective production regimes.

Feijoa and Ligustrum leaves were then harvested and cut into $10-\mathrm{mm}^{2}$ squares and fixed overnight in a solution containing $2 \%$ glutaraldehyde and $1 \%$ paraformaldehyde in a $0.1 \mathrm{M}$ phosphate buffer. Leaf segments were then critical-point-dried, gold sputter-coated, and observed with an AMR 1000A scanning electron microscope at 10 to $20 \mathrm{KeV}(1 \mathrm{ev}=$ $\left.1.602 \times 10^{-19} \mathrm{~J}\right)$. Using SEM, stomata were counted on interveinal abaxial leaf surfaces in 10 fields of known area per leaf specimen and averaged for stomatal frequency. SEM observations of adaxial leaf surfaces revealed few to no stoma, particularly for Ligustrum.

Finally, 15 leaves of each species from each treatment combination were collected for analysis of leaf area and specific leaf dry weight (SLW). Leaf area was measured using an image analysis system (DIAS Decagon Devices, Pullman, Wash.). Leaves were then oven-dried at $65 \mathrm{C}$ for $48 \mathrm{~h}$ and weighed.

Data analysis. The experiment was a two location $\times$ two paclobutrazol factorial arranged in a randomized complete-block design with four replications. For each species, an analysis of variance for the treatment main effects and interactions and an F test were calculated for data of leaf area, SLW, stomatal frequency, and spectral reflectance (400 to $900 \mathrm{~nm}$ ) using a general linear models procedure (SAS Institute, Cary, N.C.). Leaf spectral data were also separated into two wavelength intervals [photosynthetically active radiation (PAR), 400 to $700 \mathrm{~nm}$ and near infrared, 700 to $900 \mathrm{~nm}$ ], and statistical analyses were performed on these

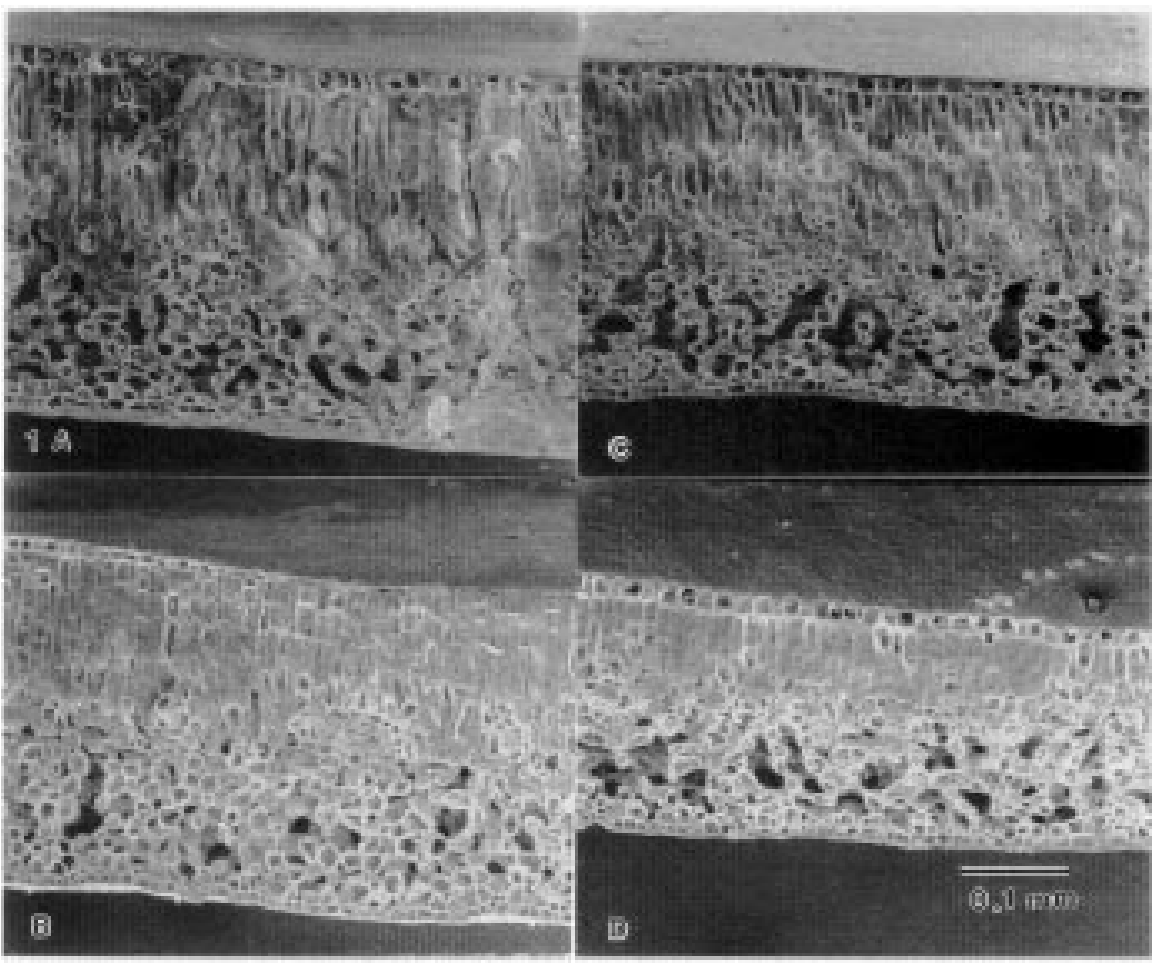

Fig. 1. Scanning electron micrographs $(\times 40$ magnification $)$ showing cross section and partial adaxial surface of a typical Ligustrum japonicum leaf. (A) Arizona control, (B) Arizona sprayed with paclobutrazol at $750 \mu \mathrm{l} \cdot \mathrm{liter}^{-1}$, (C) Georgia control, and (D) Georgia treated with paclobutrazol at $750 \mu 1 \cdot \mathrm{liter}^{-1}$.

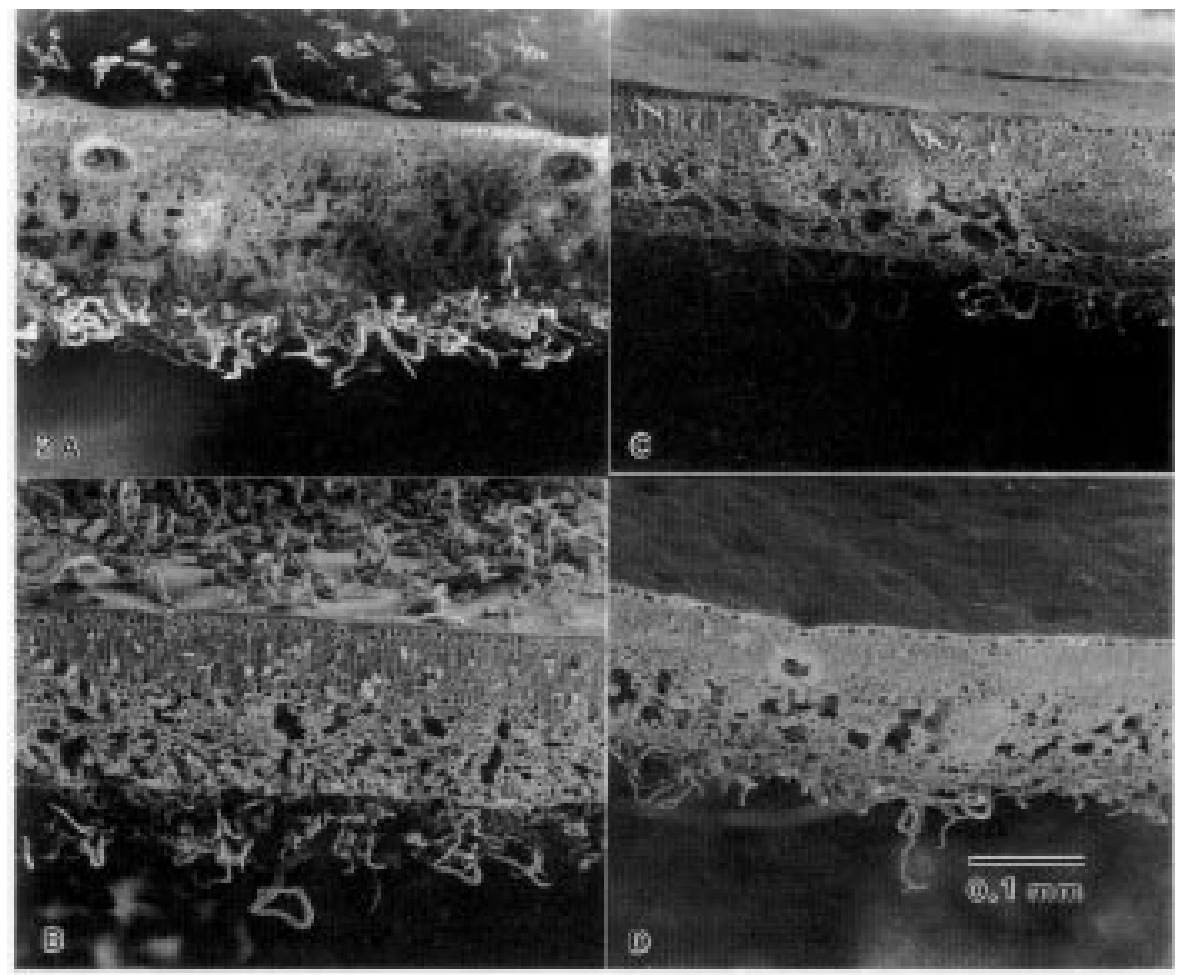

Fig. 2. Scanning electron micrographs $(\times 40$ magnification $)$ showing cross section and partial adaxial surface of a typical Feijoa sellowiana leaf. (A) Arizona control, (B) Arizona treated with paclobutrazol at 750 $\mu 1 \cdot$ liter $^{-1},(\mathbf{C})$ Georgia control, and (D) Georgia treated with paclobutrazol at $750 \mu 1 \cdot$ liter $^{-1}$. Note the increased presence of trichomes on the adaxial surface of leaves that originated in Arizona on plants treated with paclobutrazol at $750 \mu 1 \cdot$ liter $^{-1}$.

data. Second-order derivates were then calculated for leaf reflectance data between 525 and $825 \mathrm{~nm}$ (Demetriades-Shah et al., 1990; Li et al., 1993). Mathematically, the second deriva- tive depicts the rate of change of the slope of a function. This technique of differentiation has been used to suppress unwanted background signals that have reflectance curves 
that are relatively constant (O'Havers, 1982) and for resolving differences in spectral features of objects, such as leaves, that have reflectance spectra that change rapidly between 680 and $750 \mathrm{~nm}$ (Li et al., 1993).

\section{Results and Discussion}

Plant characteristics. Feijoa and Ligustrum leaves grown in Arizona were generally smaller and thicker, as expressed by SLW, than those grown in Georgia (Table 1). Leaf area of nontreated Feijoa and Ligustrum was 0.69 and 0.67 times smaller in Arizona than in Georgia, while SLW of nontreated Feijoa and Ligustrum was 1.5 and 1.3 times higher in Arizona than in Georgia. Leaf area of both species and SLW of Feijoa were affected by a location $\times$ paclobutrazol interaction (Table 1). Compared with leaves of control plants, paclobutrazol 1) increased Feijoa leaf area in Georgia, but not in Arizona; 2) decreased Ligustrum leaf area in both states by $\approx 50 \%$; and 3 ) decreased SLW of both species in Arizona, but not in Georgia (Table 1). In Georgia, leaves of paclobutrazoltreated Feijoa were 1.46 times larger than nontreated leaves; while in Arizona, paclobutrazol decreased SLW of Feijoa and Ligustrum by $25 \%$ and $19 \%$, respectively. The effect of paclobutrazol on leaf thickness of Arizona plants and leaf area of Georgia Feijoa was opposite of that reported for greenhousegrown 'Nemaguard' peach (Early and Martin, 1988). Conversely, the lack of an effect of paclobutrazol on SLW of Georgia plants was similar to that reported for southern magnolia (Martin and Ingram, 1988). SEM data corroborated measurements of SLW and showed that leaves grown in Arizona were thicker than those grown in Georgia because of more layers of palisade and spongy mesophyll cells (Figs. 1 and 2). SEM also showed that Arizona Feijoa leaves had trichomes on adaxial and abaxial surfaces, whereas Feijoa grown in Georgia had trichomes on the leaf abaxial surface only. Adaxial pubescence of Arizona Feijoa leaves is a pattern consistent with adaptations of desert species to low humidity, high light environments (Ehleringer, 1981; Ehleringer and Bjorkman, 1978; Nobel, 1978). Moreover, paclobutrazol induced increased formation of leaf trichomes on the adaxial surface of Arizona Feijoa (Fig. 2 A and B). For Feijoa and Ligustrum in Arizona, paclobutrazol appeared to reduce the density of spongy mesophyll cells; this was particularly evident with Feijoa (Fig. $2 \mathrm{C}$ and D). These changes in leaf cellular morphology might result in a reduction in SLW and an increase in mesophyll resistance to water loss because spongy mesophyll cells are packed less densely than palisade cells.

Feijoa had a higher frequency of stomata than Ligustrum irrespective of location and paclobutrazol (Table 1). In addition, Feijoa stomatal frequency was affected by the location $\times$ paclobutrazol interaction because paclobutrazol doubled Feijoa stomatal frequency in Georgia. Paclobutrazol did not change Ligustrum stomatal frequency. The lack of an effect of paclobutrazol on Ligustrum stomatal frequency contrasts with the effects of uniconazole, which increased Ligustrum stomatal frequency (Steinberg et al., 1991).

Leaf reflectance. Reflectance of solar radiation by Feijoa and Ligustrum leaves followed a sigmoidal pattern, with near-infrared reflectance plateaus occurring above $725 \mathrm{~nm}$ and small reflectance features in the green wavebands (500 to $600 \mathrm{~nm}$ ) (Fig. 3). Overall, reflectance profiles of Feijoa leaves were affected by a location $\times$ paclobutrazol interaction $\left(P>\mathrm{F}=0.001, r^{2}=0.73\right)$ (Fig. 3A), whereas Ligustrum leaf reflectance was affected by growing location $\left(P>\mathrm{F}=0.001, r^{2}\right.$ $=0.75)$ and not by paclobutrazol treatment $(P$ $>\mathrm{F}=0.952$ ) (Fig. 3B). Reflectance of nearinfrared radiation by paclobutrazol-treated Feijoa leaves was 1.4 and 1.9 times higher than that of nontreated leaves in Georgia and Arizona, respectively. Nontreated Georgia Feijoa leaves reflected $\approx 1.2$ times more near-
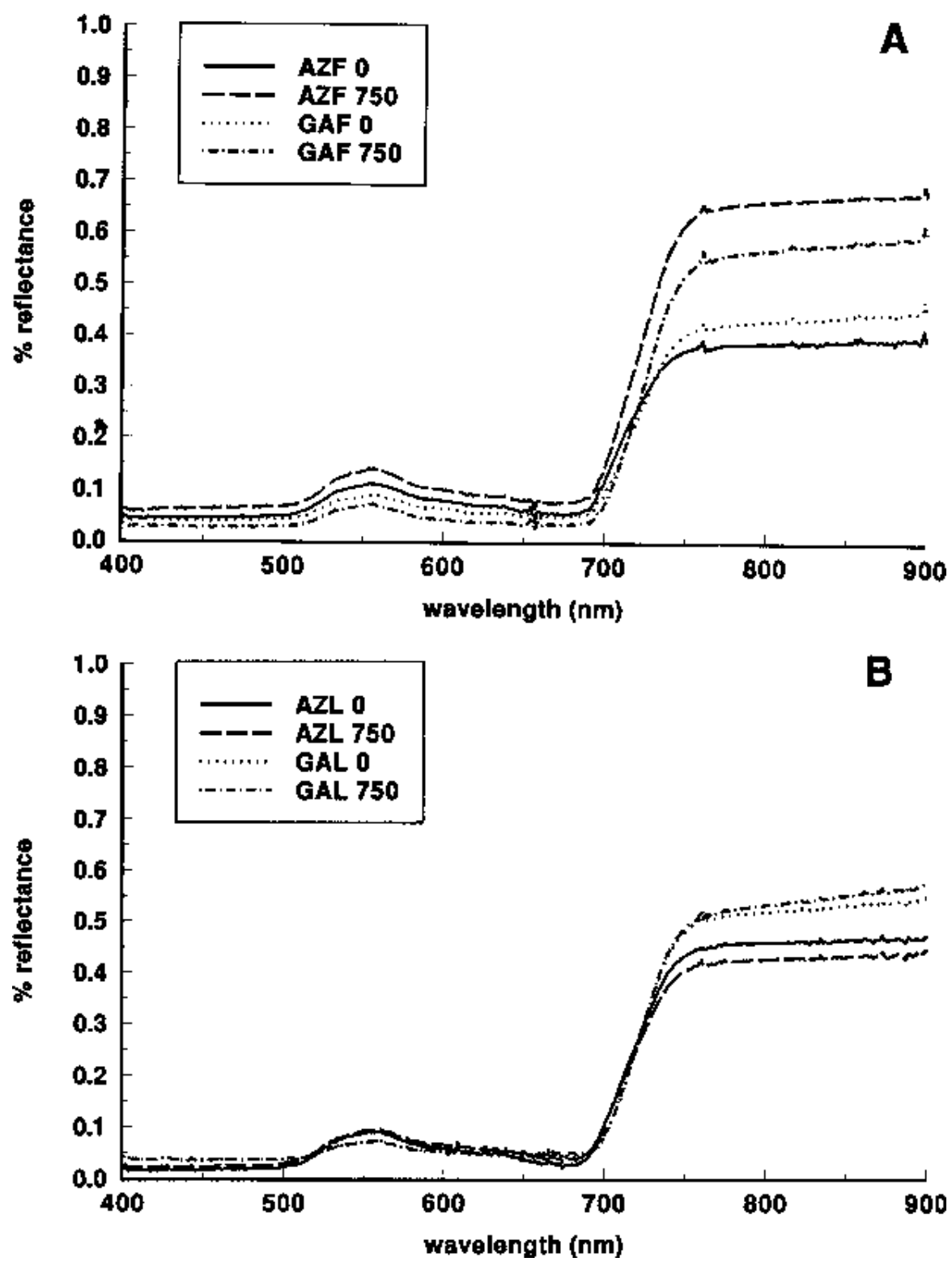

Fig. 3. Leaf reflectance spectra of (A) Feijoa sellowiana and (B) Ligustrum japonicum, as affected by location and paclobutrazol $\left(0\right.$ or $750 \mu 1 \cdot$ liter $\left.^{-1}\right)$. AZF 0 and AZF $750=$ Arizona Feijoa; GAF 0 and GAF $750=$ Georgia Feijoa $;$ AZL 0 or $750=$ Arizona Ligustrum $;$ GAL 0 or $750=$ Georgia Ligustrum 
flectance by Arizona Feijoa leaves but decreased PAR reflectance of Georgia Feijoa leaves. Paclobutrazol or location did not affect Ligustrum PAR reflectance. Increased spectral reflectance by paclobutrazol-treated compared with nontreated Arizona Feijoa leaves appeared to be directly related to increased adaxial leaf surface pubescence.

The position of maximum rate of change along the reflectance spectrum has been termed the "red edge" (Demetriades-Shah et al., 1990; Horler et al., 1983) and is usually found between 670 and $800 \mathrm{~nm}$ (Gates et al., 1985). Using the second derivate technique, shifts in the red edge of as little as $5 \mathrm{~nm}$ toward longer wavelengths were related to reduced nearinfrared reflectance in the red wavebands and increased leaf chlorophyll content (Banninger, 1990; Demetriades-Shah et al., 1990; Navarro et al., 1982; Rock et al., 1988). In our study, the red edge of Georgia leaves was shifted by $\approx 10$ $\mathrm{nm}$ to longer wavelengths compared with Arizona leaves (Fig. 4 A and B). This shift may indicate that Georgia leaves had a higher chlorophyll content than Arizona leaves, while Arizona leaves in response to a hotter, brighter growing environment had an expanded nearinfrared reflectance plateau. Data from our study contradict findings of earlier reports (Demetriades-Shah et al., 1990) because paclobutrazol caused shifts in the red edge toward longer wavelengths of $\approx 3 \mathrm{~nm}$ for Arizona Feijoa and $10 \mathrm{~nm}$ for Georgia Feijoa that were accompanied by significant increases in reflectance of near-infrared radiation (Fig. 3A). Paclobutrazol did not cause a change in the reflectance red edge of Ligustrum.

Leaves from the subtropical, desert Arizona climate were smaller and thicker compared with leaves from the humid, temperate Georgia location. The presence of trichomes on Arizona Feijoa leaves was presumably an adaptive mechanism that caused altered patterns of spectral reflectance. Paclobutrazol applied at $750 \mu \mathrm{l} \cdot$ liter $^{-1}$ primarily reduced leaf area of Ligustrum and caused Feijoa leaves to become thinner with increased pubescence in Arizona, and larger in Georgia. The concentration of paclobutrazol used in this study may improve Feijoa marketability when grown in subtropical desert regions because of enhanced plant appearance caused by increased leaf pubescence, reduced shoot internodes, and subsequent increased canopy density. Paclobutrazol may also enhance Feijoa marketability when grown in humid, temperate regions because of increased leaf area. However, the paclobutrazol concentration used in this study was probably too high because it caused excessive reductions in Ligustrum leaf area. Future research might investigate how paclobutrazol stimulated Feijoa trichome formation only under subtropical desert climatic conditions.

\section{Literature Cited}

Banninger, C. 1990. The red edge shift as a measure of stress in coniferous forests. Beltsville Agr. Res. Ctr. Symp. XV on Remote Sensing for Agr., Beltsville Agr. Res. Ctr., U.S. Dept. Agr.-
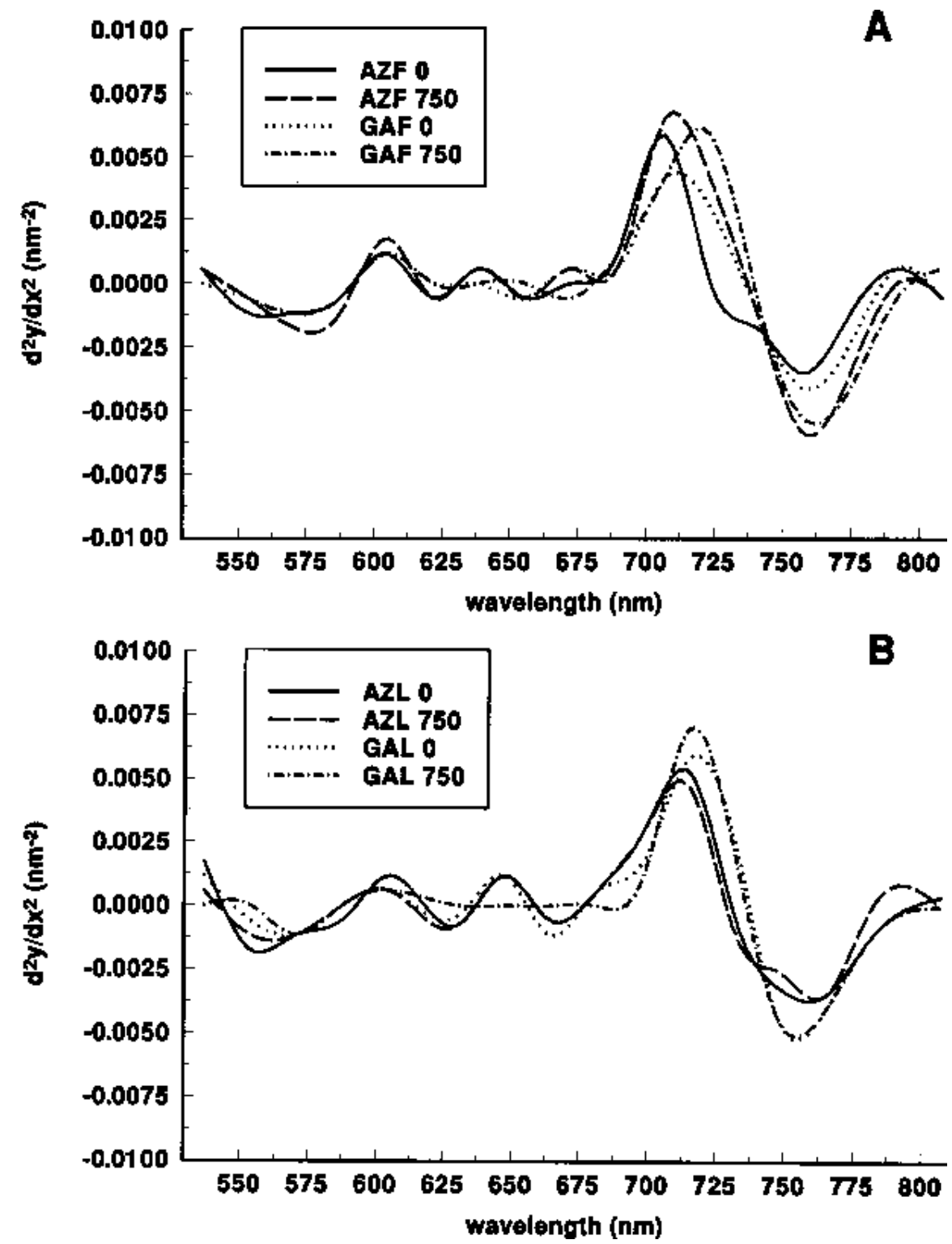

Fig. 4. The second derivatives of the partial leaf reflectance spectra by (A) Feijoa sellowiana and (B) Ligustrum japonicum, respectively, between 525 and $825 \mathrm{~nm}$, as affected by location and paclobutrazol $\left(0\right.$ or $750 \mu \mathrm{l} \cdot$ liter $\left.^{-1}\right)$. AZF 0 and AZF $750=$ Arizona Feijoa GAF 0 and GAF $750=$ Georgia Feijoa; AZL 0 or $750=$ Arizona Ligustrum; GAL 0 or $750=$ Georgia Ligustrum .

Agr. Res. Serv., Beltsville, Md., 16-18 May 1990.

Barrett, J.E. and C.A. Bartuska. 1982. PP333 effects on stem elongation dependent on site of application. HortScience 17:737-738.

Barrett, J.E. and T. Nell, 1983. Ficus benjamina response to growth retardants. Proc. Fla. State Hort. Soc. 96:264-265.

Demetriades-Shah, T.H., M.D. Steven, and J.A. Clark. 1990. High resolution derivative spectra in remote sensing. Remote Sensing Environ. 33:55-64.

Early, J.D. and G.C. Martin. 1988. Sensitivity of peach seedling vegetative growth to paclobutrazol. J. Amer. Soc. Hort. Sci. 113:23-27.

Ehleringer, J. 1981. Leaf absorptances of Mojave and Sonoran desert plants. Oecologia 49:366370.

Ehleringer, J. and O. Bjorkman. 1978. A comparison of photosynthetic characteristics of Encelia species possessing glabrous and pubescent leaves. Plant Physiol. 62:185-190.

Gates, D.M., H.J. Keegan, J.C. Schleter, and V.R. Weidner. 1985. Spectral properties of plants.
Appl. Opt. 4:11-20.

Horler, D.N.H., M. Dockray, and J. Barber. 1983. The red edge of plant reflectance. Intl. J. Remote Sensing 4:273-288.

Keever, G.J., W.J. Foster, and J.C. Stephenson. 1990. Paclobutrazol inhibits growth of woody landscape plants. J. Environ. Hort. 8:41-47.

Li, Y., T.H. Demetriades-Shah, E.T. Kanemasu, J.K. Shultis, and M.B. Kirkham. 1993. Use of second derivates of canopy reflectance for monitoring prairie vegetation over different soil backgrounds. Remote Sensing Environ. 44:81-87.

Marquard, R.D. 1985. Chemical growth regulation of pecan seedlings. HortScience 20:919-921.

Martin, C.A. and D.L. Ingram. 1988. Paclobutrazol and irradiance level affect growth of Magnolia grandiflora 'St. Mary'. Proc. Fla. State Hort. Soc. 101:316-319.

Navarro, S., L. Almela, and A.L. Garcia. 1982. Application of derivative spectroscopy to the quantitative determination of chlorophylls and related pigments. 1. Simultaneous determination of chlorophylls a and b. Photosynthetica 16:134-139. 
Nobel, P.S. 1978. Surface temperature of cactiInfluences of environmental and morphological factors. Ecology 59:986-996.

O'Havers, T.C. 1982. Derivative spectroscopy and its application in analysis: Derivative spectroscopy: Theoretical aspects. Analytical Proc. 54:22-28.

Owings, A.D. and S.E. Newman. 1993. Chemical modification of Photinia $\times$ fraseri plant size and lateral branching. J. Environ. Hort. 11:1-5.

Rock, B.N., T. Hoshizaki, and J.R. Miller. 1988. Comparison of the in situ and airborne spectral measurements of the blue shift associated with forest decline. Remote Sensing Environ. 24:109_ 127

Ruter, J.M. 1992. Growth and flowering response of butterfly-bush to paclobutrazol formulation and rate of application. HortScience 27:927.

Ruter, J.M. and C.A. Martin. 1994. Effects of contrasting climate and paclobutrazol on the growth and water use of two container-grown landscape plants. J. Environ. Hort. 12:27-33.

Steinberg, S.L., J.M. Zajicek, and M.J. McFarland. 1991. Short-term effect of uniconazole on the water relations and growth of Ligustrum. J. Amer. Soc. Hort. Sci. 116:460-464.
Swietlik, D. and S.S. Miller. 1983. The effect of paclobutrazol on growth and response to water stress of apple seedlings. J. Amer. Soc. Hort. Sci. 108:122-125.

Vogelmann, T.C. 1993. Plant tissue optics. Annu. Rev. Plant Physiol. Plant Mol. Biol. 44:231-251.

Wheeler, N.C. 1987. Effect of paclobutrazol on douglas fir and loblolly pine. J. Hort. Sci. 62:101106.

Wieland, W.F. and R.L. Wample. 1985. Root growth, water relations and mineral uptake of young delicious apples treated with soil and stem applied paclobutrazol. Scientia Hort. 26:129-137. 